\title{
Effect of INM on Soil Microbial Biomass Carbon and Enzyme Activity under Soybean of a Typic haplustepts
}

\author{
S.N. Verma*, Mahendra Sharma and Urmila
}

Department of Agricultural Chemistry and Soil Science, Rajasthan College of Agriculture, Maharana Pratap University of Agriculture and Technology, Udaipur-313001, India

*Corresponding author

\section{A B S T R A C T}

\begin{tabular}{|c|}
\hline Keywords \\
\hline $\begin{array}{l}\text { INM, Microbial } \\
\text { biomass carbon, } \\
\text { Enzymatic activity, } \\
\text { Soybean }\end{array}$ \\
\hline Article Info \\
\hline $\begin{array}{l}\text { Accepted: } \\
12 \text { December } 2017 \\
\text { Available Online: } \\
10 \text { January } 2018\end{array}$ \\
\hline
\end{tabular}

Keywords

INM, Microbial

Enzymatic activity,

Article Info

Accepted:

12 December 2017

10 January 2018

\begin{abstract}
A field experiment was conducted to study the effect of integrated nutrient management on soil microbial biomass carbon and enzyme activity under soybean of a Typic Haplustepts was conducted at Instructional Farm, Rajasthan College of Agriculture, Udaipur during consecutive Kharif seasons of the year 2014 and 2015. Among the integrated nutrient management practices, the microbial biomass carbon and enzymatic activity of soil found decreasing order from flowering to at harvesting stage as well as the depth $0-15$ and $15-30 \mathrm{~cm}$ during both the years of experiment and pooled basis. The microbial biomass carbon and enzymatic activity viz., dehydrogenase, phosphate and urease activity maximum obtaining by $75 \% \mathrm{NPK}+25$ $\% \mathrm{~N}$ through vermicompost + Rhizobium $+\mathrm{PSB}$ at flowering and harvesting stage as well as both the depth 0-15 and 15-30 cm over the 100\% NPK treatment.
\end{abstract}

\section{Introduction}

Modern agricultural practices have emphasized the widespread use of fertilizer and this approach has certainly increased grain yields in many countries in the last three decades.

However, long term use of chemical fertilizers also led to a decline in crop yields and soil fertility in the intensive cropping system. There is evidence that over fertilization has increased the concentration of many plant nutrients in both surface and ground water, which has created a potential health hazard.
There is need for integrated application of alternate source of nutrient for maintenance or adjustment of soil fertility and plant nutrient supply at an optimum level for sustaining the desired productivity. The organic manures along with biofertilizers help in reducing the dose of inorganic fertilizer, which in turn reduces the cost of cultivation and help in improving the soil health. This is achieved, through the optimization of the benefits from all possible sources of plant nutrients in an integrated manner so as to attain maximum economic yield without deleterious effect on physico-chemical and biological properties of soil. 
Bio-fertilizers are low-cost and Eco-friendly input have tremendous potential for supplying nutrients which can reduce the chemical fertilizer dose by $25-50 \%$. For increased ' $N$ ' supplies through bio-fertilizers, there is a need to inoculate the crops with effective environment of the soil by applying the deficient nutrients needed for biological nitrogen fixation. Soybean like most legumes performs nitrogen fixation by establishing symbiotic relationship with bacteria, Rhizobium japonicum. Soils containing a high microbial diversity are characteristic of a healthy soil-plant relationship, whereas those with low microbial diversity are characterized as an unhealthy soil that often hardly responds to environmental changes (Tejada et al., 2011).

Soil enzymatic activities can be used as an index of soil fertility and microbial functional diversity (Nannipieri et al., 2002; Maurya et al., 2011) in catalyzing several biochemical reactions which are necessary for the life processes of soil micro-organisms, organic wastes decomposition, organic matter formation and nutrients cycling. Incorporation of organic manures influenced soil enzymatic activity either because of the composition of the added materials themselves or because they increased microbial activity of the soil (Deforest et al., 2012). The use of organics plays a major role in maintaining soil health due to buildup of soil organic matter, beneficial microbes. Nutrients available in organic manures are released slowly, remain in the soil for longer time and are available to plants, thereby maintaining soil fertility (Belay et al., 2001).

\section{Materials and Methods}

The experiment was conducted at the Instructional Farm, Rajasthan College of Agriculture, Udaipur during Kharif 2014 and 2015. The site is situated at South-Eastern part of Rajasthan at an altitude of $579.5 \mathrm{~m}$ above mean sea level, at $24^{\circ} 35^{\prime} \mathrm{N}$ latitude and $74^{\circ} 42^{\prime}$ E longitude. The mean annual rainfall of the region is $637 \mathrm{~mm}$, most of which is contributed by south west monsoon from July to September. Maximum and minimum temperatures ranged between 25.9 to $33.7{ }^{\circ} \mathrm{C}$ and 7.7 to $22.4{ }^{\circ} \mathrm{C}$, respectively during kharif. The soil of experimental site are well drained, clayey with moderate erosion and classified as clayey mixed, Hyperthermic (Calcareous) Typic haplustepts containing clay loam in texture, neutral to alkaline in reaction (7.55), medium in available nitrogen $\left(231.30 \mathrm{~kg} \mathrm{ha}^{-1}\right)$ and phosphorus (16.00 kg ha $\mathrm{kg}^{-1}$, high in available potassium (309.20 kg ha $\left.\mathrm{ha}^{-1}\right)$, Microbial biomass carbon (168 $\mathrm{mg} \mathrm{kg}^{-1}$ ), Dehydrogenase activity $\left(9.60 \mu \mathrm{gTPFg}^{-1}\right.$ soil), Phosphate activity $\left(13.80 \mu \mathrm{g} \mathrm{g}^{-1} \mathrm{~h}^{-1}\right)$ and Urease activity $\left(99.20 \mu \mathrm{g} \mathrm{g}^{-1}\right.$ soil $\left.\mathrm{h}^{-1}\right)$. The experiment was laid out in a Randomized Block Design (RBD) with four replications with soybean cultivar JS-336. Treatments were randomly distributed within the blocks as follows: $100 \% \mathrm{NPK}\left(\mathrm{T}_{1}\right), 100 \% \mathrm{NPK}+$ Rhizobium + PSB $\left(\mathrm{T}_{2}\right), 75 \% \mathrm{NPK}+25 \% \mathrm{~N}$ through FYM $\left(\mathrm{T}_{3}\right), 75 \% \mathrm{NPK}+25 \% \mathrm{~N}$ through FYM + Rhizobium + PSB $\left(\mathrm{T}_{4}\right), 75 \%$ $\mathrm{NPK}+25 \% \mathrm{~N}$ through $\mathrm{VC}\left(\mathrm{T}_{5}\right), 75 \% \mathrm{NPK}+$ $25 \% \mathrm{~N}$ through $\mathrm{VC}+$ Rhizobium $+\mathrm{PSB}\left(\mathrm{T}_{6}\right)$, $50 \% \mathrm{NPK}+50 \% \mathrm{~N}$ through $\mathrm{FYM}\left(\mathrm{T}_{7}\right), 50 \%$ $\mathrm{NPK}+50 \% \mathrm{~N}$ through FYM + Rhizobium + PSB $\left(\mathrm{T}_{8}\right), 50 \% \mathrm{NPK}+50 \% \mathrm{~N}$ through VC $\left(\mathrm{T}_{9}\right), 50 \% \mathrm{NPK}+50 \% \mathrm{~N}$ through $\mathrm{VC}+$ Rhizobium + PSB $\left(\mathrm{T}_{10}\right), 50 \% \mathrm{NPK}+25 \% \mathrm{~N}$ through $\mathrm{VC}+25 \% \mathrm{~N}$ through FYM $\left(\mathrm{T}_{11}\right), 50$ $\% \mathrm{NPK}+25 \% \mathrm{~N}$ through $\mathrm{VC}+25 \% \mathrm{~N}$ through FYM + Rhizobium + PSB ( $\left.\mathrm{T}_{12}\right)$. Doses of $\mathrm{P}_{2} \mathrm{O}_{5}$ (SSP) were applied before the sowing and thoroughly mixed in soil. The seeds were inoculated with and phosphate solubilizing bacteria (PSB) at $200 \mathrm{~g}$ each for $10 \mathrm{~kg}$ of seeds just before dibbling as per treatments. After inoculation seeds were dried in the shade for about one hour and then used for dibbling. The Microbial biomass carbon of 
soil was determined by Standard serial dilution and plate count method (Vance et al., 1987), Dehydrogenase activity by colorimetric determination of TPF (Casida et al., 1964), Phosphate activity by modified universal buffer (MUB) method and Urease activity by Non-buffer method (Tabatabai and bremner, 1969).

\section{Results and Discussion}

\section{Soil microbial biomass carbon}

It is evident from the data presented in (Table 1) revealed that the microbial biomass carbon (MBC) value in soil decreased from flowering to at harvesting stage as well as depths $0-15$ and $15-30 \mathrm{~cm}$.

The maximum microbial biomass carbon at 015 and 15-30 cm depth $(287,289,288$ and $233,236,235 \mathrm{mg} \mathrm{kg}^{-1}$ ) at flowering stage and $\left(244,250,247\right.$ and 195, 237, $\left.216 \mathrm{mg} \mathrm{kg}^{-1}\right)$ at harvest stage of soybean were found in treatment receiving $75 \% \mathrm{NPK}+25 \% \mathrm{~N}$ through vermicompost + Rhizobium $+\mathrm{PSB}$ $\left(\mathrm{T}_{6}\right)$ respectively, it is significantly superior over rest of the treatments and statically at par with the in the treatment obtaining by 75 and $50 \% \mathrm{NPK}+25$ and $50 \% \mathrm{~N}$ through either vermicompost or FYM.

The minimum microbial biomass carbon recorded under application of inorganic treatment alone $100 \%$ NPK $\left(\mathrm{T}_{1}\right)$ at both the depths. Use of FYM and vermicompost alone or in combination with chemical fertilizers significantly increased the soil microbial biomass carbon (SMB-C). It might be due to the supply of additional mineralizable and readily hydrolysable $\mathrm{C}$ due to organic manure application resulted in higher microbial activity and in return higher microbial biomass carbon. Wright and Hons (2005), Thakare and Bhoyar (2012) and Datt et al., (2013) have also reported similar findings.

\section{Enzymatic activity (Dehydrogenase, phosphate and urease) in soil}

\section{Dehydrogenase activity}

Data related to dehydrogenase activity under the influence of integrated nutrient management practices are presented in (Table 2) emphasized that the application of different organic manures and inorganic fertilizers were found significant with respect to dehydrogenase activity during both the years and pooled basis.

The dehydrogenase activity in soil was found in decreasing trend at flowering to harvest stage as well as depths i.e. 0-15 and $15-30 \mathrm{~cm}$ during both the years and pooled basis.

The highest dehydrogenase activity $\mu \mathrm{gTPFg}^{-}$ ${ }^{1}$ soil produced at flowering and harvest of soybean was found $(37.96,39.09,38.52$ and 27.20, 27.48, $27.34 \mu_{\mathrm{gTPFg}^{-1}}$ soil) under application of $75 \% \mathrm{NPK}+25 \% \mathrm{~N}$ through vermicompost + Rhizobium $+\mathrm{PSB}\left(\mathrm{T}_{6}\right)$ which was significantly superior over rest of the treatments and statistically at par with the 75 $\% \mathrm{NPK}+25 \% \mathrm{~N}$ through vermicompost $\left(\mathrm{T}_{5}\right)$ and $50 \% \mathrm{NPK}+25 \% \mathrm{~N}$ through $\mathrm{VC}+25 \%$ $\mathrm{N}$ through $\mathrm{FYM}+$ Rhizobium + PSB $\left(\mathrm{T}_{12}\right)$, respectively during both the years and pooled basis.

The inorganic fertilizer treatment alone i.e., $100 \%$ NPK failed to increase dehydrogenase activity in the soil.

The lower activity of soil enzyme activity in recommended dose of fertilizers as compared to other treatments with manures may be attributed to the lack of sufficient substrate i.e., organic carbon which acts as energy source for proliferating microbial population. Similar results were also reported by Lizarazo et al., (2005), Ramesh et al., (2008) and Aher et al., (2015). 
Table.1 Effect of INM on microbial biomass carbon $\left(\mathrm{mg} \mathrm{kg}^{-1}\right)$ at flowering and harvest stage of soybean at different depths

\begin{tabular}{|c|c|c|c|c|c|c|c|c|c|c|c|c|}
\hline \multirow[t]{3}{*}{ Treatments } & \multicolumn{6}{|c|}{ At flowering stage } & \multicolumn{6}{|c|}{ At harvest stage } \\
\hline & \multicolumn{3}{|c|}{$(0-15 \mathrm{~cm})$} & \multicolumn{3}{|c|}{$(15-30 \mathrm{~cm})$} & \multicolumn{3}{|c|}{$(0-15 \mathrm{~cm})$} & \multicolumn{3}{|c|}{$(15-30 \mathrm{~cm})$} \\
\hline & 2014 & 2015 & Pooled & 2014 & 2015 & Pooled & 2014 & 2015 & Pooled & 2014 & 2015 & Pooled \\
\hline$\overline{T_{1}}$ & 173 & 164 & 169 & 110 & 119 & 115 & 134 & 128 & 131 & 101 & 100 & 100 \\
\hline$T_{2}$ & 172 & 181 & 177 & 112 & 127 & 119 & 136 & 142 & 139 & 105 & 109 & 107 \\
\hline$T_{3}$ & 203 & 212 & 208 & 133 & 158 & 145 & 167 & 173 & 170 & 120 & 140 & 130 \\
\hline$T_{4}$ & 257 & 266 & 262 & 157 & 182 & 169 & 191 & 197 & 194 & 122 & 165 & 143 \\
\hline$T_{5}$ & 283 & 288 & 286 & 232 & 233 & 233 & 241 & 247 & 244 & 192 & 234 & 213 \\
\hline$T_{6}$ & 287 & 289 & 288 & 233 & 236 & 235 & 244 & 250 & 247 & 195 & 237 & 216 \\
\hline$T_{7}$ & 280 & 283 & 282 & 224 & 225 & 224 & 236 & 240 & 238 & 131 & 173 & 152 \\
\hline$T_{8}$ & 280 & 283 & 282 & 225 & 225 & 225 & 236 & 240 & 238 & 142 & 187 & 165 \\
\hline$T_{9}$ & 281 & 283 & 283 & 225 & 226 & 225 & 237 & 239 & 239 & 149 & 191 & 170 \\
\hline $\mathrm{T}_{10}$ & 282 & 283 & 282 & 226 & 227 & 227 & 236 & 242 & 239 & 173 & 215 & 194 \\
\hline$T_{11}$ & 283 & 284 & 283 & 227 & 230 & 229 & 238 & 244 & 241 & 182 & 224 & 203 \\
\hline$T_{12}$ & 284 & 286 & 285 & 228 & 231 & 230 & 242 & 248 & 245 & 187 & 229 & 208 \\
\hline SEm \pm & 5.45 & 2.65 & 3.03 & 2.76 & 5.25 & 2.96 & 4.32 & 4.74 & 3.21 & 3.02 & 3.54 & 2.32 \\
\hline CD at $5 \%$ & 15.68 & 7.64 & 8.56 & 7.94 & 15.09 & 8.37 & 12.45 & 13.65 & 9.06 & 8.7 & 10.19 & 6.57 \\
\hline
\end{tabular}

Table.2 Effect of INM on dehydrogenase activity $\left(\mu \mathrm{gTPFg}^{-1}\right.$ soil) at flowering and harvest stage of soybean at different depths

\begin{tabular}{|c|c|c|c|c|c|c|c|c|c|c|c|c|}
\hline \multirow[t]{3}{*}{ Treatments } & \multicolumn{6}{|c|}{ At flowering stage } & \multicolumn{6}{|c|}{ At harvest stage } \\
\hline & \multicolumn{3}{|c|}{$(0-15 \mathrm{~cm})$} & \multicolumn{3}{|c|}{$(15-30 \mathrm{~cm})$} & \multicolumn{3}{|c|}{$(0-15 \mathrm{~cm})$} & \multicolumn{3}{|c|}{$(15-30 \mathrm{~cm})$} \\
\hline & 2014 & 2015 & Pooled & 2014 & 2015 & Pooled & 2014 & 2015 & Pooled & 2014 & 2015 & Pooled \\
\hline $\mathrm{T}_{1}$ & 12.70 & 16.06 & 14.38 & 10.10 & 12.01 & 11.06 & 11.70 & 11.86 & 11.78 & 10.55 & 10.71 & 10.63 \\
\hline$T_{2}$ & 15.12 & 19.80 & 17.46 & 10.52 & 15.75 & 13.14 & 12.12 & 14.28 & 13.20 & 11.97 & 12.13 & 12.05 \\
\hline$T_{3}$ & 21.10 & 24.13 & 22.62 & 20.32 & 22.08 & 21.20 & 18.10 & 20.26 & 19.18 & 14.95 & 15.11 & 15.03 \\
\hline$T_{4}$ & 23.20 & 24.48 & 23.84 & 21.21 & 22.43 & 21.82 & 20.20 & 22.36 & 21.28 & 15.21 & 17.05 & 16.13 \\
\hline$T_{5}$ & 37.22 & 38.60 & 37.91 & 26.80 & 26.87 & 26.84 & 29.05 & 30.21 & 29.63 & 21.80 & 27.06 & 24.43 \\
\hline $\mathrm{T}_{6}$ & 37.96 & 39.09 & 38.52 & 27.20 & 27.48 & 27.34 & 29.45 & 30.51 & 29.98 & 22.20 & 27.26 & 24.73 \\
\hline$T_{7}$ & 34.72 & 38.20 & 36.46 & 20.40 & 20.67 & 20.53 & 26.65 & 27.81 & 27.23 & 16.40 & 21.66 & 19.03 \\
\hline$T_{8}$ & 35.45 & 36.01 & 35.73 & 13.30 & 21.40 & 17.35 & 27.46 & 27.62 & 27.54 & 17.21 & 22.47 & 19.84 \\
\hline$T_{9}$ & 36.28 & 37.12 & 36.70 & 15.40 & 22.23 & 18.81 & 27.57 & 27.73 & 27.65 & 19.32 & 24.58 & 21.95 \\
\hline$\overline{T_{10}}$ & 37.38 & 38.01 & 37.70 & 23.33 & 24.21 & 23.77 & 27.46 & 27.62 & 27.54 & 20.21 & 25.47 & 22.84 \\
\hline$T_{11}$ & 35.92 & 36.25 & 36.09 & 18.45 & 21.87 & 19.81 & 24.70 & 26.86 & 25.78 & 14.45 & 19.71 & 17.08 \\
\hline$T_{12}$ & 37.48 & 38.38 & 37.93 & 26.68 & 26.83 & 26.76 & 28.83 & 29.49 & 29.16 & 21.66 & 26.84 & 24.25 \\
\hline SEm \pm & 0.48 & 0.73 & 0.44 & 0.35 & 0.41 & 0.27 & 0.61 & 0.32 & 0.34 & 0.39 & 0.24 & 0.23 \\
\hline CD at $5 \%$ & 1.38 & 2.10 & 1.24 & 1.02 & 1.20 & 0.77 & 1.76 & 0.94 & 0.98 & 1.13 & 0.69 & 0.65 \\
\hline
\end{tabular}


Table.3 Effect of INM on phosphate activity $\left(\mu \mathrm{g} \mathrm{g}^{-1} \mathrm{~h}^{-1}\right)$ at flowering and harvest stage of soybean at different depths

\begin{tabular}{|c|c|c|c|c|c|c|c|c|c|c|c|c|}
\hline \multirow[t]{3}{*}{ Treatments } & \multicolumn{6}{|c|}{ At flowering stage } & \multicolumn{6}{|c|}{ At harvest stage } \\
\hline & \multicolumn{3}{|c|}{$(0-15 \mathrm{~cm})$} & \multicolumn{3}{|c|}{$(15-30 \mathrm{~cm})$} & \multicolumn{3}{|c|}{$(0-15 \mathrm{~cm})$} & \multicolumn{3}{|c|}{$(15-30 \mathrm{~cm})$} \\
\hline & 2014 & 2015 & Pooled & 2014 & 2015 & Pooled & 2014 & 2015 & Pooled & 2014 & 2015 & Pooled \\
\hline$\overline{T_{1}}$ & 30.78 & 32.14 & 31.46 & 21.53 & 25.87 & 23.70 & 21.23 & 24.89 & 23.06 & 18.34 & 21.73 & 20.04 \\
\hline$\frac{1}{T_{2}}$ & 31.88 & 32.24 & 32.06 & 22.63 & 26.97 & 24.80 & 22.33 & 25.99 & 24.16 & 19.44 & 22.83 & 21.14 \\
\hline$T_{3}$ & 24.30 & 26.66 & 25.48 & 15.05 & 19.39 & 17.22 & 14.75 & 18.41 & 16.58 & 10.99 & 15.25 & 13.12 \\
\hline$T_{4}$ & 30.42 & 32.78 & 31.60 & 21.17 & 25.51 & 23.34 & 20.87 & 24.53 & 22.70 & 17.98 & 21.37 & 19.68 \\
\hline$T_{5}$ & 32.42 & 33.78 & 33.10 & 22.66 & 27.14 & 24.90 & 23.87 & 25.53 & 24.70 & 22.98 & 23.07 & 23.03 \\
\hline$T_{6}$ & 32.56 & 33.92 & 33.24 & 23.11 & 28.05 & 25.58 & 24.01 & 25.77 & 24.89 & 23.12 & 23.61 & 23.37 \\
\hline$T_{7}$ & 20.56 & 22.92 & 21.74 & 14.89 & 15.65 & 15.27 & 11.01 & 14.67 & 12.84 & 10.25 & 11.51 & 10.88 \\
\hline$T_{8}$ & 28.98 & 31.34 & 30.16 & 19.73 & 24.07 & 21.90 & 19.43 & 23.09 & 21.26 & 15.67 & 19.93 & 17.80 \\
\hline$T_{9}$ & 28.63 & 30.99 & 29.81 & 19.38 & 23.78 & 21.58 & 19.08 & 22.74 & 20.91 & 15.32 & 19.58 & 17.45 \\
\hline $\mathrm{T}_{10}$ & 29.95 & 32.31 & 31.04 & 20.70 & 25.03 & 22.87 & 20.40 & 24.06 & 22.23 & 17.51 & 20.90 & 19.21 \\
\hline$T_{11}$ & 29.22 & 31.58 & 30.40 & 19.97 & 24.31 & 22.14 & 19.67 & 23.33 & 21.50 & 16.78 & 20.17 & 18.48 \\
\hline$T_{12}$ & 31.98 & 32.34 & 32.16 & 22.53 & 27.07 & 24.80 & 23.43 & 25.09 & 24.26 & 22.84 & 23.03 & 22.94 \\
\hline SEm \pm & 0.66 & 0.51 & 0.42 & 0.36 & 0.55 & 0.33 & 0.35 & 0.25 & 0.21 & 0.28 & 0.22 & 0.18 \\
\hline CD at $5 \%$ & 1.89 & 1.48 & 1.18 & 1.03 & 1.59 & 0.93 & 1.01 & 0.73 & 0.66 & 0.80 & 0.64 & 0.50 \\
\hline
\end{tabular}

Table.4 Effect of INM on urease activity $\left(\mu \mathrm{g} \mathrm{g}^{-1}\right.$ soil $\left.^{-1}\right)$ at flowering and harvest stage of soybean at different depths

\begin{tabular}{|c|c|c|c|c|c|c|c|c|c|c|c|c|}
\hline \multirow[t]{3}{*}{ Treatments } & \multicolumn{6}{|c|}{ At flowering stage } & \multicolumn{6}{|c|}{ At harvest stage } \\
\hline & \multicolumn{3}{|c|}{$(0-15 \mathrm{~cm})$} & \multicolumn{3}{|c|}{$(15-30 \mathrm{~cm})$} & \multicolumn{3}{|c|}{$(0-15 \mathrm{~cm})$} & \multicolumn{3}{|c|}{$(15-30 \mathrm{~cm})$} \\
\hline & 2014 & 2015 & Pooled & 2014 & 2015 & Pooled & 2014 & 2015 & Pooled & 2014 & 2015 & Pooled \\
\hline $\mathrm{T}_{1}$ & 128.70 & 129.12 & 128.91 & 107.82 & 112.23 & 110.03 & 92.70 & 96.20 & 94.45 & 75.24 & 80.00 & 77.62 \\
\hline$T_{2}$ & 130.00 & 130.42 & 130.21 & 108.12 & 111.53 & 109.83 & 93.00 & 96.50 & 94.75 & 76.54 & 81.30 & 78.92 \\
\hline $\mathbf{T}_{3}$ & 114.30 & 114.67 & 114.49 & 100.42 & 100.84 & 100.63 & 87.30 & 91.80 & 89.55 & 65.84 & 70.60 & 68.22 \\
\hline $\mathrm{T}_{4}$ & 116.20 & 116.91 & 116.56 & 100.32 & 100.73 & 100.53 & 89.20 & 93.70 & 91.45 & 66.74 & 71.50 & 69.12 \\
\hline$T_{5}$ & 136.00 & 136.65 & 136.33 & 110.12 & 113.57 & 111.85 & 96.00 & 100.50 & 98.25 & 82.54 & 87.30 & 84.92 \\
\hline$T_{6}$ & 136.80 & 137.25 & 137.03 & 111.92 & 114.24 & 113.08 & 97.80 & 102.30 & 100.05 & 84.34 & 89.10 & 86.72 \\
\hline$T_{7}$ & 108.70 & 109.43 & 109.07 & 101.82 & 104.23 & 103.06 & 81.70 & 86.20 & 83.95 & 60.24 & 65.00 & 62.62 \\
\hline$T_{8}$ & 110.30 & 111.11 & 110.70 & 103.42 & 107.83 & 105.63 & 83.30 & 87.80 & 85.55 & 61.84 & 66.60 & 64.22 \\
\hline$T_{9}$ & 134.70 & 135.14 & 134.92 & 106.82 & 108.23 & 107.53 & 95.70 & 97.20 & 96.45 & 81.24 & 86.00 & 83.62 \\
\hline$T_{10}$ & 132.40 & 132.83 & 132.62 & 104.52 & 105.93 & 105.23 & 96.00 & 98.50 & 97.25 & 78.94 & 83.71 & 81.32 \\
\hline$T_{11}$ & 129.30 & 129.72 & 129.51 & 105.42 & 106.83 & 106.13 & 92.30 & 96.80 & 94.55 & 75.84 & 80.60 & 74.22 \\
\hline$T_{12}$ & 135.00 & 135.44 & 135.22 & 110.02 & 113.53 & 111.78 & 96.40 & 99.90 & 98.15 & 82.49 & 86.99 & 84.74 \\
\hline SEm \pm & 1.43 & 3.06 & 1.69 & 1.42 & 1.47 & 1.02 & 1.25 & 1.45 & 0.96 & 1.13 & 1.34 & 0.88 \\
\hline CD at $5 \%$ & 4.12 & 8.81 & 4.77 & 3.10 & 3.23 & 2.65 & 3.60 & 4.16 & 2.70 & 3.26 & 3.87 & 2.48 \\
\hline
\end{tabular}




\section{Phosphate activity}

Data presented in (Table 3) application of nutrients either through inorganic or in combination with organic sources and biofertilizers significantly influenced phosphate activity at $0-15$ and $15-30 \mathrm{~cm}$ depth during both the years of experiment and pooled basis. The maximum phosphate activity at $0-15$ and $15-30 \mathrm{~cm}$ depth $(32.56$, $33.92,33.24$ and $23.11,28.05,25.58 \mu \mathrm{g} \mathrm{g}^{-1}$ $\left.\mathrm{h}^{-1}\right)$ at flowering and $(24.01,25.77,24.89$ and 23.12, 23.61, $23.37 \mu \mathrm{g} \mathrm{g}^{-1} \mathrm{~h}^{-1}$ ) at harvest were found in treatment obtaining by $75 \% \mathrm{NPK}+$ $25 \% \mathrm{~N}$ through vermicompost + Rhizobium + PSB $\left(\mathrm{T}_{6}\right)$ which was significantly superior over rest of the treatments (Table 3). Enzyme activity decreased from flowering to harvest stage of crop. The minimum phosphate activity at $0-15$ and $15-30 \mathrm{~cm}$ depths were observed under application of $50 \%$ NPK +50 $\% \mathrm{~N}$ through FYM $\left(\mathrm{T}_{7}\right)$. Soil phosphatase activity are the most important in plant nutrition, these are involved in mineralization of organically bound phosphorus to inorganic phosphorus compounds in soil. The sharp increase in the enzyme activities at flowering which coincides with the active growth stage of the crop, enhanced root activity and the release of extracellular enzymes like urease and phosphatase into soil solutions during the active growth phase which resulted in higher rate of mineralization of nutrients in the soil. The results were in conformity with the findings of Jagadeesh (2000), Datt et al., (2013) and Aher et al., (2015).

\section{Urease activity}

An assessment of data presented in (Table 4) showed that urease activity in soil affected due to enriched fertility of soil via application of nutrients either through inorganic or in combination with organic sources to soybean crop during both the years of experiment and pooled basis as well as both depths.
Significantly highest urease activity in soil $\left(136.80,137.25\right.$ and $137.03 \mu \mathrm{g} \mathrm{g}^{-1}$ soil $\left.\mathrm{h}^{-1}\right)$ at $0-15 \mathrm{~cm}$ and (111.92, 114.24 and $113.08 \mu \mathrm{g}$ $\mathrm{g}^{-1}$ soil $\left.\mathrm{h}^{-1}\right)$ at $15-30 \mathrm{~cm}$ depth at flowering and $\left(97.80,102.30\right.$ and $100.05 \mu \mathrm{g} \mathrm{g}^{-1}$ soil h $\left.\mathrm{h}^{-1}\right)$ at $0-15 \mathrm{~cm}$ and $\left(84.34,89.10\right.$ and $86.72 \mu \mathrm{g} \mathrm{g}^{-1}$ soil $\mathrm{h}^{-1}$ ) at $15-30 \mathrm{~cm}$ depth at harvest of crop were estimated under influence of $75 \%$ NPK $+25 \% \mathrm{~N}$ through vermicompost + Rhizobium $+\mathrm{PSB}\left(\mathrm{T}_{6}\right)$ which statistically remained at par with crop receiving treatments $75 \%$ NPK + $25 \% \mathrm{~N}$ through vermicompost $\left(\mathrm{T}_{5}\right)$ and $50 \%$ $\mathrm{NPK}+25 \% \mathrm{~N}$ through VC $+25 \% \mathrm{~N}$ through $\mathrm{FYM}+$ Rhizobium + PSB $\left(\mathrm{T}_{12}\right)$ during both the years of experiment and pooled basis as well as both the depths (Table 4) over 100\% NPK through chemical fertilizer. Urease is unique among soil enzymes and greatly affects the fate and performance of important fertilizer like urea. Soil urease catalysis the hydrolysis of urea to carbon dioxide and $\mathrm{NH}_{4}{ }^{+}$ a form assimilable by plants. The results of investigation corroborate the findings of Suryanarayan Reddy (2002), Raju et al., (2013) and Datt et al., (2013).

From the above study it can be concluded that the application of chemical fertilizer with organic manure and biofertilizers with integration viz., $75 \%$ NPK through chemical fertilizer $+25 \%$ other rest of $\mathrm{N}$ through vermicompost and seeds should be dual inoculated with Rhizobium + PSB significantly improved soil microbial biomass carbon and enzymatic activity in soil. Thus the objective of maximizing organic carbon content and enzymatic activity for sustaining soil fertility for long term basis and maintain soil health can be furnished by a balanced use of inorganic fertilizers conjunctively with biological and organic manure.

\section{References}

Aher, S. B., Lakaria, B. L., Kaleshananda, S., Singh, A. B., Ramana, S., Ramesh K. and Thakur, J. K. 2015. Effect of organic farming practices on 
soil and performance of soybean (Glycine max) under semi-arid tropical conditions in Central India. Journal of Applied and Natural Science, 7(1): 67-71.

Belay, A., Classens, A. S., Wehner, F. C., De Beer, J. M. 2001. Influence of residual manure on selected nutrient elements and microbial composition of soil under long-term crop rotation. South African Journal of Plant and Soil, 18: 1-6.

Casida, I. E., Klein, D. A. and Santore, T. 1964. Measurement of dehydrogenase activity by incubating the soil with TTC method. Soil Science, 98: 373.

Datt, N., Dubey, Y. P. and Chaudhary, R. 2013. Studies on impact of organic, inorganic and integrated use of nutrients on symbiotic parameters, yield, and quality of French-bean (Phaseolus vulgaris L.) vis-à-vis soil properties of an acid Alfisol. African Journal of Agricultural Research, 8 (22): 2645-2654.

Deforest, J. L., Smemo, K. A., Burke, D. J., Elliott, H. L. and Becker, J. C. 2012. Soil microbial responses to elevated phosphorus and $\mathrm{pH}$ in acidic temperate deciduous forests. Biogeochemistry, 109:189-202.

Jagadeesh, B. R. 2000. Chemical and biochemical properties of soil subjected to permanent manurial and cropping schedule. Journal of the Indian Society Soil Science, 48 (2): 283-286.

Lizarazo, M. L., Jorda, J. P. S. and Juarez, M. 2005. Effect of humic amendments on inorganic N, dehydrogenase and alkaline phosphates activities of a Mediterranean soil. Biol. Fert. Soil, 42: 172-177.

Maurya, B. R., Vimal, S. and Dhyani, P. P. 2011. Enzymatic activities and microbial population in agri-soils of Almora district of central Himalaya as influenced by altitudes. International Journal of Soil Science, 6: 238248.

Nannipieri, P., Kandeler, E., and Ruggiero P. 2002. Enzyme activities and microbial and biochemical processes in soil. In: Burns, RG and Dick RP (Eds.), Enzymes in the Environment: Activity, Ecology and Applications. Marcel Dekker, New York, 1-33.

Raju, B., Chandrasekhar, P. Rao, A., Reddy, P. K. and Padmavathi, P. 2013. Effect of Various INM Practices on Yield, Urease and Dehydrogenase activity in Safflower. Helix Vol. 6: $405-408$.

Ramesh P., Panwar, N. R., Singh, A. B. and Ramana, S. 2008. Effect of organic manure on productivity, soil fertility and economics of soybean (Glycine max) - duram wheat (Triticum duram) cropping system under organic farming in vertisols. Indian Journal of Agriculture Science, 78 (12): 1033-1037.

Suryanarayan Reddy, M. 2002. Relationship between organic carbon and soil enzymes. Journal of Research ANGRAU, 30 (2): 143146.

Tabatabai M. A. and Bremner, J. M. 1969. Use of pnitrophenol for assess of soil phosphatase activity. Soil Biology and Biochemistry, 1: 301307.

Tejada M, Benítez C, Gómez I, Parrado J. 2011. Use of bio stimulants on soil restoration: Effects on soil biochemical properties and microbial community. Applied Soil Ecology, 49: 11-17.

Thakare, R. and Bhoyar, S. 2012. Dynamics of soil biological fertility as influenced by organic and inorganic inputs under soybean in vertisols. Asian Journal of Soil Science, 7 (1): 18-22.

Vance, E. D., Brookes, P. C. and Jenkinson, D. S. 1987. An extraction method for measuring soil microbial biomass carbon. Soil Biology and Biochemistry, 19: 703- 707.

Wright, A. L. and Hons, F. M. 2005. Soil carbon and nitrogen storage in aggregates from different tillage and crop regimes. Soil Science Society of America Journal, 69: 141-147.

\section{How to cite this article:}

Verma, S.N., Mahendra Sharma and Urmila. 2018. Effect of INM on Soil Microbial Biomass Carbon and Enzyme Activity under Soybean of a Typic haplustepts. Int.J.Curr.Microbiol.App.Sci. 7(01): 1312-1318. doi: https://doi.org/10.20546/ijcmas.2018.701.160 